\title{
PERHITUNGAN PREMI DENGAN PENERAPAN DEDUCTIBLE PADA MODEL AKTUARIA UNTUK SICKNESS INSURANCE PERTANGGUNGAN SATU TAHUN
}

\section{Premium Calculation with the Application of Deductible in Actuarial Model for One Year Sickness Insurance}

\author{
N. Lewaherilla ${ }^{1^{*}}$, G. Haumahu ${ }^{2}$ \\ ${ }^{1,2}$ Program Studi Statistika, Jurusan Matematika, Fakultas MIPA UniversitasPattimura \\ Jln. Ir. M. Putuhena, KampusUnpatti - Poka, Ambon, 97233, Provinsi Maluku, Indonesia \\ e-mail: lewaherillanorisca@gmail.com*
}

\begin{abstract}
Abstrak: Asuransi kesehatan adalah produk asuransi yang memberikan manfaat jika tertanggung terkena risiko kecelakaan atau sakit dan menyebabkan hilangnya pendapatan, sehingga membutuhkan biaya. Manfaat paling penting dalam penelitian ini dari sickness insurance adalah penggantian biaya pengobatan. Desain penentuan premi dengan menerapkan deductible (flat deductible) dipandang sebagai salah satu kebijakan polis asuransi yang memenuhi prinsip-prinsip penentuan premi. Aspek aktuaria yang dipertimbangkan dalam model asuransi kesehatan dalam penelitian ini untuk perhitungan premi yang berkaitan dengan jenis tunjangan asuransi dengan penggantian biaya (reimbursement) untuk masa pertanggungan satu tahun, dengan memperhatikan jenis pekerjaan. Tujuan dari penelitian ini adalah untuk melihat penerapan deductible terhadap premi yang harus dibayarkan kepada perusahaan asuransi yang memberikan manfaat untuk klaim yang diajukan. Kebijakan menerapkan deductible mengubah besarnya reimbursement.
\end{abstract}

Kata Kunci: deductible, sickness insurance, premi, reimbursement.

\begin{abstract}
Health insurance is an insurance product that provides benefits if the insured is exposed to the risk of an accident or illness and causes loss of income, thus requiring costs. The most important benefit in this study from sickness insurance is the reimbursement of medical expenses. The design of determining premiums by applying deductibles (flat deductibles) is seen as one of the insurance policy policies that meet the principles of determining premiums. The actuarial aspects considered in the health insurance model in this study for the calculation of premiums relating to the type of insurance benefits with expense reimbursement for a period of one year coverage, with due regard to the type of work. The purpose of this study is to see the applied of deductible to the premiums that must be paid to insurance companies that provide benefits for claims submitted. The policy of applying deductibles certainly makes the amount of reimbursement change.
\end{abstract}

Keywords: deductible, sickness insurance, premium, reimbursement.

\section{PENDAHULUAN}

Asuransi kesehatan merupakan suatu produk asuransi yang memberikan manfaat jika tertanggung terkena risiko kecelakaan atau sakit dan menyebabkan hilangnya pendapatan, sehingga membutuhkan biaya. Biaya yang dibutuhkan dapat berupa biaya rawat inap, tindakan medis, bedah, obat-obatan, biaya rawat jalan, dan lain sebagainya. Secara garis besar, asuransi kesehatan diklasifikasikan menjadi sickness insurance, accident insurance, income protection, critical illness insurance, long-term care insurance. Lebih lanjut tentang asuransi kesehatan secara umum dan klasifikasinya dapat dibaca pada [1].

Kewajiban yang harus dibayar oleh pihak tertanggung yakni berupa premi. Prinsip-prinsip mendasar yang harus dipertimbangkan dalam perhitungan premi [2] adalah harus cukup dana untuk 
membayar biaya klaim dan biaya lainnya, yang diatur sedemikian sehingga tidak terjadi perang harga dan merugikan konsumen (pihak tertanggung). Prinsip selanjutnya terkait dengan kewajaran terhadap manfaat yang diberikan. Apabila terlalu banyak profit dan biaya, akan mengurangi fungsi asuransi, di samping harus berdasarkan kemampuan membayar. Dengan demikian diperlukan desain produk sickness insurance, yang dapat memenuhi prinsip-prinsip dasar tersebut, sehingga baik pihak pemberi tanggungan maupun tertanggung tidak mengalami kerugian sepihak.

Penelitian ini difokuskan pada produk sickness insurance perusahaan asuransi (pihak swasta), dimana manfaat dapat diberikan jika tertanggung sakit. Manfaat yang diberikan pada sickness insurance bervariasi, sesuai jenis dan kebijakan perpanjangan polis asuransi. Manfaat yang paling penting dalam dari sickness insurance [1] adalah reimburstment (penggantian biaya) pengobatan. Reimbursement yang dilakukan berupa: pertanggungan rawat inap di rumah sakit mencakup semua layanan yang diperoleh tertanggung (termasuk bedah, tes laboratorium, obat-obatan, dan lain-lain); perlindungan rawat jalan berkaitan dengan layanan oleh dokter dan/atau rumah sakit, termasuk bedah kecil; manfaat lanjutan seperti tes laboratorium dan obat yang diresepkan oleh dokter. Untuk manfaat rawat inap, biasanya maksimal rentang manfaat disesuaikan dengan kebijakan yang diterapkan. Pada penelitian ini akan difokuskan untuk rentang waktu satu tahun pertanggungan.

Desain penentuan premi dengan menerapkan deductible (flat deductible) dipandang sebagai salah satu kebijakan polis asuransi yang memenuhi prinsip-prinsip penentuan premi. Deductible adalah jumlah yang telah ditentukan untuk dibayar oleh tertanggung sebelum pemberi tanggungan menanggung atau menutupi sisa biaya sebagai selisih biaya tanggungan dengan biaya yang ditentukan. [3] Misal kebijakan asuransi dengan per-loss deductible yaitu $d$. Jika tanggungan sebesar $x$, dimana $x \leq d$, maka asuransi tidak membayar apapun. Akan tetapi jika tanggungan $x>d$, asuransi akan dibayarkan sebesar $x-d$. Aspek aktuaria yang diperhatikan pada model asuransi kesehatan pada penelitian ini, baik untuk perhitungan premi maupun cadangan premi berkaitan dengan tipe manfaat pertanggungan dengan expense reimbursement untuk jangka waktu satu tahun pertanggungan terhadap single premium, dengan memperhatikan jenis pekerjaan.

Tujuan penelitian ini adalah untuk membuat model aktuaria dari penerapan deductible pada manfaat reimbursement sickness insurance pertanggungan satu tahun. Dari model yang dibuat, akan ditunjukkan dampak dari penerapan deductible baik yang dirasakan pihak pemberi tanggungan maupun tertanggung, dengan menggunakan data yang diperoleh dari hasil simulasi.

\section{METODOLOGI}

Penelitian ini dilakukan dengan metode deskriptif yang memberi gambaran dari model aktuaria khusus untuk sickness insurance. Manfaat asuransi yang diperhatikan pada sickness insurance ini difokuskan pada rawat inap dan perlindungan rawat jalan. Data yang digunakan untuk melihat manfaat tersebut adalah adalah data sekunder yang kemudian disimulasikan dengan membangkitkan data random tertentu dan dibuat resampling jika memenuhi kondisi tertentu, dengan kebijakan polis yang spesifik untuk pertangunggan satu tahun.

Sampel diambil melihat sickness insurance rawat inap dan rawat jalan mempertimbangkan tipe pekerja dengan risiko tertentu. Risiko klaim yang muncul dapat lebih dari satu klaim namun tetap dalam periode pertanggungan selama satu tahun. Sampel dipilih berdasarkan jenis usaha peserta yang kemudian dikategorikan sebagai tipe pekerja, yaitu: (1) Pekerja kantoran, yang dipilih dengan menggabungkan jenis usaha jasa teknologi informatika, asuransi, perbankan, dan karyawan asosiasi; (2) Pekerja lapangan, yang dipilih dengan menggabungkan jenis usaha jasa umum dan jasa konstruksi; (3) Pekerja pabrik, yang dipilih dengan menggabungkan jenis usaha pabrik dan pabrik tekstil.

Lama rawat inap diasumsikan berdistribusi Poisson, dengan parameternya diambil dari jumlah frekuensi lama rawat inap dibagi dengan total lama rawat inap. Diasumsikan rata-rata lama rawat 
inap di kamar adalah 6 hari, sedangkan rata-rata lama rawat inap di ICU adalah 1 hari. Banyaknya peserta, exposure, dan banyaknya kejadian sakit dari sampel dapat dilihat pada tabel berikut.

Tabel 1. Banyaknya Kejadian Untuk Setiap Tipe Pekerja

\begin{tabular}{|c|c|c|c|c|c|c|}
\hline \multirow[b]{2}{*}{ Tipe Pekerja } & \multirow{2}{*}{$\begin{array}{c}\text { Banyaknya } \\
\text { Peserta }\end{array}$} & \multirow[b]{2}{*}{ Exposure } & \multirow{2}{*}{$\begin{array}{c}\text { Banyaknya } \\
\text { Kejadian } \\
\text { Rawat Inap }\end{array}$} & \multicolumn{2}{|c|}{ Banyaknya Kejadian Rawat Jalan } & \multirow{2}{*}{$\begin{array}{c}\text { Total } \\
\text { Kejadian } \\
\text { Sakit }\end{array}$} \\
\hline & & & & Dokter Umum & Dokter Spesialis & \\
\hline Pekerja Kantoran & 7.922 & 7.317 & 273 & 450 & 810 & 1.533 \\
\hline Pekerja Lapangan & 4.186 & 4.046 & 70 & 145 & 333 & 548 \\
\hline Pekerja Pabrik & 42.184 & 41.048 & 30 & 132 & 170 & 332 \\
\hline Total & 54.292 & 69.683 & 273 & 727 & 1.313 & 2.413 \\
\hline
\end{tabular}

Frekuensi orang sakit diperoleh dari banyakya tiap kejadian dibagi exposure tiap kategori dimana hasilnya dapat dilihat pada tabel berikut.

Tabel 2. Frekuensi Orang Sakit Setiap Tipe Pekerja

\begin{tabular}{|l|r|r|r|}
\hline \multirow{2}{*}{ Tipe Pekerja } & \multirow{2}{*}{ Rawat Inap } & \multicolumn{2}{|c|}{ Rawat Jalan } \\
\cline { 3 - 4 } & & Dokter Umum & Dokter Spesialis \\
\hline Pekerja Kantoran & 0,04 & 0,06 & 0,1 \\
\hline Pekerja Lapangan & 0,02 & 0,04 & 0,08 \\
\hline Pekerja Pabrik & 0,001 & 0,003 & 0,004 \\
\hline
\end{tabular}

Peluang kejadian diperoleh dari banyaknya kejadian masing-masing rawat inap dan rawat jalan dibagi dengan total pasiennya. Peluang dokter umum pada rawat inap hanya menggunakan menggunakan frekuensi lamanya rawat inap karena setiap pasien yang dirawat inap sudah pasti mendapat perawatan dari dokter umum. Untuk melakukan resampling pada beberapa jenis biaya diperlukan distribusi yang sesuai beserta parameternya, sehingga perlu dilakukan fitting distribusi.

Informasi yang diperoleh dari pengolahan data tersebut akan digunakan untuk melakukan perhitungan selanjutnya, yakni perhitungan claim amount dan premi dari setiap tipe pekerja. Kemudian dimasukkan dalam model aktuaria sickness insurance, hingga penerapan deductible di dalamnya. Pada bagian ini akan terlihat nilai selisih yang harus dikeluarkan oleh pemberi tanggungan jika besaran klaim lebih dari deductible yang ditentukan.

\section{HASIL DAN PEMBAHASAN}

\subsection{Notasi, Asumsi, dan Estimasi Statistik [2]}

Misalkan:

$N$ : Banyaknya klaim acak tertanggung selama satu tahun periode pertanggungan (random claim frequency), $=0,1,2, \ldots$.

$X_{j} \quad$ : Besarnya pembayaran klaim ke-j oleh tertanggung.

$Y_{j} \quad$ : Besarnya pertanggungan klaim ke-j oleh pihak yang menanggung, atau disebut claim amount atau claim severity. Misal kebijakan polis asuransi yaitu $Y_{j} \geq X_{j}$. Penggantian biaya klaim mengacu pada masing-masing klaim, dengan flat deductible.

$S$ : Total pertanggungan tahunan, atau disebut aggregate claim amount.

Secara umum, dapat dituliskan

$$
S=\Phi\left(N ; Y_{1}, Y_{2}, \ldots, Y_{N}\right)
$$


Secara khusus, jika kebijakan yang ditentukan tidak membatasi total annual amount dari manfaat, maka dapat dituliskan:

$$
S=\left\{\begin{array}{cc}
0 & , \text { jika } N=0 \\
Y_{1}+Y_{2}+\cdots+Y_{N} & , \text { jika } N>0
\end{array}\right.
$$

Perhitungan premi menggunakan prinsip ekuivalensi, dimana ekuivalensi premi diperoleh dari ekspektasi total pembayaran tahunan kepada tertanggung, yaitu:

$$
\Pi=E[S]
$$

$E[S]$ diasumsikan menyatakan peubah acak $X_{1}, X_{2}, \ldots, X_{N}$ yang independen dari peubah acak $N$. Realisasinya, yaitu $n$, dari peubah acak $X_{1}, X_{2}, \ldots, X_{N}$ bersifat mutually independent dan identically distributed. Jika $Y_{j}=\varphi\left(X_{j}\right)$, untuk $j=1,2, \ldots, n$, maka peubah acak $Y_{1}, Y_{2}, \ldots, Y_{n}$ juga identically distributed. Misal diambil distribusi peluang $Y_{1}$, maka secara umum dapat dituliskan nilai ekspektasinya yaitu $\mathbb{E}\left[Y_{1}\right]$. Dengan demikian, ekspektasi aggregate claim amount $\mathbb{E}[S]$ diperoleh dari:

$$
\mathbb{E}[S]=\mathbb{E}\left[Y_{1}\right] \mathbb{E}[N]
$$

Misal $\mathcal{Q}$ menyatakan premi observasi, dimana net premium $\Pi=\mathcal{Q}$. Rasio antara total pembayaran terhadap banyaknya kebijakan (claim amount per policy) dapat ditulis sebagai berikut.

$$
\mathcal{Q}=\frac{y_{1}+y_{2}+\cdots+y_{z}}{r}
$$

Persamaan (5) ini dapat disebut sebagai risk premium atau average claim cost. Nilai $\mathcal{Q}$ mewakili estimasi dari $\mathbb{E}[S]$. Misalkan $r$ menyatakan banyaknya risiko tertanggung dan $z$ menyatakan banyaknya klaim pada portofolio, maka $\bar{n}=\frac{z}{r}$ menyatakan rataan frekuensi klaim. Rata-rata besarnya nilai klaim dapat ditulis sebagai berikut.

$$
\bar{y}=\frac{y_{1}+y_{2}+\cdots+y_{z}}{z}
$$

Misalkan pula, $d_{1}, d_{2}, \ldots, d_{z}$ menyatakan lamanya klaim $z$ (dalam hari), dan $b$ menyatakan manfaat harian, maka dapat ditulis rata-rata besar klaim per polis yaitu:

$$
\mathcal{Q}=b \frac{d_{1}+d_{2}+\cdots+d_{z}}{r}=b \mu
$$

Average length per claim dinyatakan dalam persamaan berikut:

$$
\bar{d}=\frac{d_{1}+d_{2}+\cdots+d_{z}}{Z}
$$

Ditulis $\bar{n}$ menyatakan nilai estimasi $\mathbb{E}[N]$, dan $b \bar{d}$ menyatakan estimasi $\mathbb{E}\left[Y_{1}\right]$.

\subsection{Biaya Rawat Inap dan Rawat Jalan}

Biaya-biaya yang timbul pada sickness insurance yaitu biaya kamar, biaya ICU, biaya kunjungan dokter umum, biaya dokter spesialis, dan biaya aneka. Perhitungan dapat dilakukan dengan menggunakan Persamaan (1) sampai (8) untuk mengestimasi banyaknya kalim dan besarnya pertanggungan klaim. Dapat pula dilakukan hal yang sama dari portofolio.

Biaya rawat inap diperoleh dari rata-rata biaya per hari per pasien yaitu Rp. 201.660 untuk biaya kamar, Rp. 171.598 untuk biaya ICU, Rp. 74.099 untuk biaya kunjungan dokter umum. Untuk setiap pasien, rata-rata biaya kamar dan biaya dokter dikalikan dengan lama hari rawat inap yang telah dibangkitkan menggunakan random Poisson, dengan rata-rata lama rawat inap 4 hari. Biaya aneka dibangkitkan dengan random lognormal dengan rataan Rp. 14,807, dan simpangan baku Rp.1.108, dan syarat resampling jika biaya lebih dari Rp. 4.707.091,127. Sedangkan biaya bedah diperoleh dari data yang dibangkitkan dengan random uniform. Peluang pembedahan yang diperoleh adalah 0,2. 
Untuk perlindungan rawat inap, simulasi random Poisson dilakukan untuk mendapatkan frekuensi orang yang akan berkunjung ke dokter umum frekuensi kunjungan $0,06,0,04$, dan 0,003 untuk setiap tipe pekerja. Kemudian dilakukan random normal untuk resampling untuk menentukan biaya obat dan random uniform untuk untuk biaya laboratorium dan biaya biaya terapi. Hal serupa pun dilakukan untuk menentukan frekuensi kunjungan ke dokter spesialis, namun berbeda pada frekuensi kunjungan yaitu 0,1, 0,08, 0,004. Biaya untuk kunjungan ke dokter umum adalah Rp. 59.619, dokter spesialis Rp. 72.282, biaya pemeriksaan laboratorium Rp. 323.243, biaya terapi Rp. 117.282. Simulasi dilakukan dengan sebanyak 100 kali untuk exposure 69.683, untuk memperoleh biaya klaim dan premi. Biaya yang ditetapkan rumah sakit untuk sekali kunjungan ke dokter umum adalah Rp.50.000, dokter spesialis Rp.100.000, biaya pemeriksaan laboratorium Rp.150.000, biaya terapi Rp.100.000. Simulasi dilakukan dengan sebanyak 100 kali untuk 10.000 orang, untuk memperoleh biaya klaim dan premi.

Besarnya premi yang harus dibayarkan dan besarnya nilai pertanggungan dalam asuransi kesehatan sangat tergantung kepada program asuransi kesehatan yang dipilih. Total biaya klaim diperoleh sebagai aggregat dari setiap manfaat biaya pada rawat inap. Kemudian dilakukan pengulangan simulasi sebanyak 100 kali untuk memperoleh rata-rata total biaya klaim yang harus dicadangkan perusahaan serta premi yang harus dibayar oleh pihak tertanggung.

Tabel 3. Perbandingan Rataan Besar Klaim dan Premi Berdasarkan Tipe Pekerja Untuk Rawat Inap

\begin{tabular}{|l|r|r|r|}
\hline \multicolumn{1}{|c|}{ Tipe Pekerja Kantoran } & Pekerja Kantoran & Pekerja Lapangan & Pekerja Pabrik \\
\hline Rataan Besar Biaya Klaim & Rp. 30.881.840.609 & Rp. 15.509.759.714 & Rp. 761.364.154 \\
\hline Simpangan baku & Rp. 702.565.178 & Rp. 573.534.622 & Rp. 119.302.349 \\
\hline Maximum & Rp. 33.004.399.353 & Rp. 17.052.902.331 & Rp. 1.020 .104 .529 \\
\hline Minimum & Rp. 29.389.674.840 & Rp. 14.424.155.223 & Rp. 472.102.644 \\
\hline \multicolumn{4}{|c|}{} \\
\hline Rataan premi & Rp. 443.176,1 & Rp. 222.575,9 & Rp. 10.926,11 \\
\hline Simpangan baku premi & Rp. 10.082,3 & Rp. 8.230,625 & Rp. 1.712,073 \\
\hline Maximum & Rp. 473.636,3 & Rp. 244.721,1 & Rp. 14.639,22 \\
\hline Minimum & Rp. 421.762,5 & Rp. 206.996,8 & Rp. 6.775,005 \\
\hline
\end{tabular}

Perhitungan peluang dokter umum diabaikan dengan asumsi setiap pasien yang dirawat inap sudah pasti mendapat perawatan dari dokter umum setiap harinya. Peluang pasien rawat inap mendapat kamar adalah 1 karena pasien sudah pasti mendapatkan manfaat kamar. Sama halnya dengan rawat inap, frekuensi rawat jalan diperoleh dari banyakya tiap kejadian dibagi exposure tiap kategori . Hanya saja frekuensi rawat jalan dibagi atas frekuensi pasien yang berkunjung ke dokter umum dan kunjungan langsung ke dokter spesialis tanpa melalui dokter umum terlebih dahulu. Peluang yang perlu dihitung dalam proses rawat jalan adalah peluang pasien untuk menjalani fisioterapi dan pemeriksaan laboratorium. Peluang pada rawat jalan diperoleh dari banyaknya kejadian masing-masing fisioterapi dan laboratorium dibagi dengan total pasien rawat jalan. Manfaat yang ditawarkan pada rawat jalan adalah konsultasi dokter umum, konsultasi dokter spesialis, obat-obatan, pemeriksaan diagnostik, dan fisioterapi. Tabel 4 menyatakan hasil perbandingan manfaat rawat jalan untuk ketiga tipe pekerja.

Tabel 4. Perbandingan Rataan Besar Klaim dan Premi Berdasarkan Tipe Pekerja Untuk Rawat Jalan

\begin{tabular}{|l|r|r|r|}
\hline \multicolumn{1}{|c|}{ Tipe Pekerja Kantoran } & Pekerja Kantoran & Pekerja Lapangan & \multicolumn{1}{c|}{ Pekerja Pabrik } \\
\hline Rataan Besar klaim & Rp. 39.804 .146 .016 & Rp. 38.839.419.193 & Rp. 39.688.182.071 \\
\hline Simpangan baku & Rp. 142.443 .352 & Rp. 102.626 .138 & Rp. 121.000 .864 \\
\hline Maximum & Rp. 40.168.857.606 & Rp. 39.224.992.554 & Rp. 40.023.421.058 \\
\hline Minimum & Rp. 39.479.703.081 & Rp. 38.610.511.795 & Rp. 39.415.040.953 \\
\hline \multicolumn{4}{|c|}{} \\
\hline Rataan premi & Rp. 571.217.5 & Rp. 557.372.9 & Rp. 569.553.3 \\
\hline Simpangan baku premi & Rp. 2.044.162 & Rp. 1.472 .757 & Rp. 1.736 .447 \\
\hline Maximum & Rp. 576.451.3 & Rp. 562,906.2 & Rp. 574.364.2 \\
\hline Minimum & Rp. 566.561.5 & Rp. 554.088 & Rp. 565.633.5 \\
\hline
\end{tabular}




\subsection{Perhitungan Premi dengan Penerapan Deductible}

Misal $u$ menyatakan nilai yang harus dibayarkan (out of the pocket) oleh tertanggung (pasien) atas biaya perawatan yang diperoleh, a menyatakan generic expense amount, dan $D$ menyatakan flat deductible yang ditentukan. Dengan proportional deductible $(\alpha)$, stop loss (SL), nilai yang bergantung pada nilai $D(M)$, maka dapat ditulis:

$$
u=\left\{\begin{array}{ccc}
x & , & \text { jika } x<D \\
a(x-D)+D & , & \text { jika } D \leq x<M \\
S L & , & \text { jika } x \geq M
\end{array}\right.
$$

dengan $M=\frac{1}{a}(S L-(1-a) D)$. Besarnya manfaat reimbursement yang dibayarkan pihak penanggung dinyatakan dengan $y$, yaitu:

$$
y=\left\{\begin{array}{ccc}
0 & , & \text { jika } x<D \\
(1-a)(x-D) & , & \text { jika } D \leq x<M \\
x-S L & , & \text { jika } x \geq M
\end{array}\right.
$$

Dengan memasukkan hasil perhitungan biaya pertanggungan rawat inap dan rawat jalan ke Persamaan (9) sampai (10), maka dapat diperoleh nilai yang harus ditanggung oleh pihak tertanggung maupun pemberi tanggungan, sesuai tipe pekerja dan nilai deductible yang ditentukan. Nilai deductible hendaknya ditentukan dengan tidak merugikan pihak tertentu.

Perhitungan premi diawali dengan mengasumsikan nilai-nilai $\bar{y}_{x}, \bar{n}_{x}, \bar{d}_{x}$ diestimasi untuk umur $x, x \in\left[x_{\text {min }}, x_{\text {max }}\right]$ pada rentang umur pertanggungan. Untuk kelebihan pembiayaan medis dengan kebijakan reimbursement, maka:

$$
\Pi_{x}=\bar{y}_{x} \bar{n}_{x}(1+i)^{-\frac{1}{2}}
$$

dengan manfaat harian $b$, maka premi diperoleh:

Dari Persamaan (12), jika dimisalkan untuk rawat inap, dengan deductible yang ditetapkan sebesar Rp. 100.000 dan misalkan pula $i$ sebagai besarnya bunga dalam setahun pertanggungan sebesar 5\%, maka diperoleh premi untuk rawat inap dan rawat jalan sebagai berikut.

Tabel 5. Premi Rawat Inap Rumah Sakit

\begin{tabular}{|l|r|r|r|}
\hline & \multicolumn{1}{|c|}{ Risiko Rendah } & Risiko Sedang & \multicolumn{1}{c|}{ Risiko Tinggi } \\
\hline Frekuensi Pasien & 207 orang & 304 orang & 396 orang \\
\hline Biaya Kamar & Rp.81.600.000 & Rp.112.000.000 & Rp.156.700.000 \\
\hline Biaya Dokter & Rp.40.800.000 & Rp.61.000.000 & Rp.78.350.000 \\
\hline Biaya Bedah & Rp.546.246.885 & Rp.984.208.852 & Rp.1.304.925.482 \\
\hline Biaya ICU & Rp.25.800.000 & Rp.28.200.000 & Rp.64.500.000 \\
\hline Biaya Dokter Spesialis & Rp.6.750.000 & Rp. 9.375.000 & Rp.12.525.000 \\
\hline Biaya Aneka & Rp.880.362.199 & Rp. 1.284 .285 .461 & Rp.1.758.808.107 \\
\hline Total Biaya Klaim & Rp.1.581.559.084 & Rp.2.489.069.313 & Rp.3.375.808.589 \\
\hline Premi & Rp.158.155,9 & Rp.248.906,9 & Rp.337.580,9 \\
\hline Premi dengan deductible & Rp. 56.754 & Rp. 242.908,3 & Rp.329.445,2 \\
\hline
\end{tabular}

Berdasarkan hasil perhitungan yang ditampilkan pada tabel, maka dapat dihitung berapa besar yang harus dibayarkan tertanggung dan berapa besar reimbursement yang dapat diterima.

\begin{tabular}{|r|r|r|}
\hline Expense Amount $x$ & Out of pocket $u$ & \multicolumn{2}{|l|}{ Reimburesement benefit $y$} \\
\hline Rp. 56.754 & Rp. 56.754 & 0 \\
\hline Rp. $242.908,3$ & Rp.142.908,3 & Rp.142.908,3 \\
\hline Rp.329.445,2 & Rp.229.445,2 & Rp.229.445,2 \\
\hline
\end{tabular}




\section{KESIMPULAN}

Diberlakukannya kebijakan penerapan deductible berpengaruh besarnya reimbursement. Dari hasil perhitungan diperoleh besarnya reimbursement sama dengan besarnya uang yang dikeluarkan oleh tertanggung setelah diterapkan deductible. Dengan demikian hal ini menjadi sharing expense amount baik bagi tertanggung maupun pemberi tanggungan dalam pertanggungan sickness insurance.

\section{DAFTAR PUSTAKA}

[1] E. Pitacco, Health Insurance: Basic Actuarial Models, Switzerland: Springer International, 2004.

[2] Y. Hendrartini. Metode Perhitungan Premi Sebagai Dasar Penetapan Biaya Kesehatan. Retrieved Juni 1, 2019, from www.academia.edu

[3] A. S. Klugman, H. H. Panjer, \& G.E. Willmot, G. E, Loss Models from Data to Decision, Second Edition. New Jersey: John Wiley \& Sons Inc, 1949. 